\title{
Sources and fates of silicon in the ocean: the role of diatoms in the climate and glacial cycles*
}

\author{
R.C. DUGDALE and F.P. WILKERSON \\ Romberg Tiburon Center, San Francisco State University, 3152 Paradise Drive, Tiburon CA 94920, USA. \\ E-mail: rdugdale@sfsu.edu
}

\begin{abstract}
SUMMARY: Diatoms with their fast growth rates and obligate requirement for Si have a unique relationship to the oceanic $\mathrm{Si}$ cycle with the potential for controlling the nutrient and $\mathrm{CO}_{2}$ environment of large important areas of the ocean. The new production of diatoms based on both new nitrogen and Si sources is described using a Si-pump based upon the differential regeneration of the two elements. This approach, applied to the eastern equatorial Pacific, showed diatoms to respond as in a Si-limited chemostat, to the low source $\mathrm{Si}(\mathrm{OH})_{4}$ in the Equatorial UnderCurrent. Increased $\mathrm{Si}(\mathrm{OH})_{4}$ results in increased diatom productivity, suppression of non-diatom populations and decreased surface $\mathrm{pCO}_{2}$. The deficiency in source concentrations of $\mathrm{Si}(\mathrm{OH})_{4}$ results from low $\mathrm{Si}(\mathrm{OH})_{4}: \mathrm{NO}_{3}$ water originating in the vicinity of the Antarctic Polar Front, a consequence of the extraordinary trapping of Si by the Southern Ocean. In glacial periods this trapping is reduced several fold and likely results in increased $\mathrm{Si}(\mathrm{OH})_{4}$ export to the north, and increased $\mathrm{Si}(\mathrm{OH})_{4}$ production and deposition at the equatorial Pacific which can be expected to reduce surface $\mathrm{pCO}_{2}$. The connections between the eastern equatorial Pacific export production and Southern Ocean Si trapping may provide a major biogeochemical feedback system with implications for contemporary and paleoclimatology.
\end{abstract}

Key words: silicon, nitrogen, phytoplankton, diatom, carbon productivity, Equatorial Pacific, Southern Ocean, paleoclimatology.

\section{INTRODUCTION}

The biogeochemistry of silicon $(\mathrm{Si})$ is the focus of considerable contemporary attention by geochemists, paleoceanographers and paleoclimatologists. Biologists are showing revived interest in the $\mathrm{Si}$ cycle in relation to diatom productivity as it's very strong role in marine productivity (e.g. Smetacek, 1999) and effect on ocean-atmosphere processes becomes apparent, following a period in which the focus was almost exclusively on smaller and smaller planktonic organisms. The objective of this communication is to review the role of biologi-

\footnotetext{
*Received June 8, 2001. Accepted July 5, 2001.
}

cal processes in the formation of the ocean Si environment first at the broad scale and then in more detail in two special settings, the equatorial Pacific and the Southern Ocean. In doing so, we will follow the evolution of a set of nitrogen $(\mathrm{N})$ based models, that conclude with inclusion of Si and it's impact on global carbon cycles and paleoclimatology. We will examine the differences between the oceanic Si and $\mathrm{N}$ cycle, the existence of areas of unusually low silicate relative to nitrate concentrations and how we think they are formed. The concept of the Pacific equatorial upwelling area as a Si limited chemostatlike system and the model complexity necessary to describe its functioning will be presented. The low $\mathrm{Si}(\mathrm{OH})_{4}$ condition of the equatorial Pacific 
upwelling system will be discussed, along with possible connections between the equator and the Southern Ocean with implications for contemporary and paleoclimatology. This communication is by no means a broad and unbiased view of a piece of modern oceanography, but rather traces the evolution of our present ideas on the role of diatoms in some key ocean processes.

Dissolved silicon enters the ocean as silicic acid or silicate $\left(\mathrm{Si}(\mathrm{OH})_{4}\right)$ from the rivers as a result of weathering of siliceous rocks although some enters also from atmospheric deposition of particles. Through the action of the Broecker conveyer belt (Broecker and Peng, 1982), $\mathrm{Si}(\mathrm{OH})_{4}$ is fractionated between the major ocean basins with the result that the Atlantic Ocean is generally poor in $\mathrm{Si}(\mathrm{OH})_{4}$ at depth compared to the Pacific where very high concentrations up to $170 \mathrm{mmol} . \mathrm{m}^{-3}$ occur in the deep water of the north Pacific (Rageneau et al., 2000). Deep waters from each basin are drawn into the Antarctic Circumpolar Current and released in slow northward currents to furnish water for upwelling. However, a large portion of the annual input of Si to the oceans is trapped in the Southern Ocean through production of biogenic silica $(\mathrm{BSi})$ primarily by diatoms, and exported to the ocean bed, forming a circumpolar band of high Si sediment.

\section{THE CONTRAST IN ELEMENTAL REGENER- ATION OF SILICON VERSUS NITROGEN}

The difference between $\mathrm{N}$ and $\mathrm{Si}$ regeneration can be seen qualitatively in Figure 1, representative of much of the world ocean. Nitrate $\left(\mathrm{NO}_{3}\right)$ increases more rapidly with depth than $\mathrm{Si}(\mathrm{OH})_{4}$ and reaches a maximum value at relatively shallow depths. $\mathrm{Si}(\mathrm{OH})_{4}$ increases more slowly with depth and continues to increase almost all the way to the bottom depths of the ocean. While organic nitrogen is degraded and oxidized through microorganismal activity high in the water column, the $\mathrm{Si}$ from diatom shells or tests is re-dissolved by chemical processes more slowly as particles containing BSi sink.

The nitrogen production and regeneration cycle can be diagrammed simplistically as in Figure 2. New nitrogen sources to the euphotic zone are $\mathrm{NO}_{3}$ advected vertically, fixation of atmospheric nitrogen $\left(\mathrm{N}_{2}\right)$ and ammonium $\left(\mathrm{NH}_{4}\right)$ and $\mathrm{NO}_{3}$ contained in precipitation. $\mathrm{NH}_{4}$ produced by bacterial degradation of particulate organic nitrogen (PON) occurs

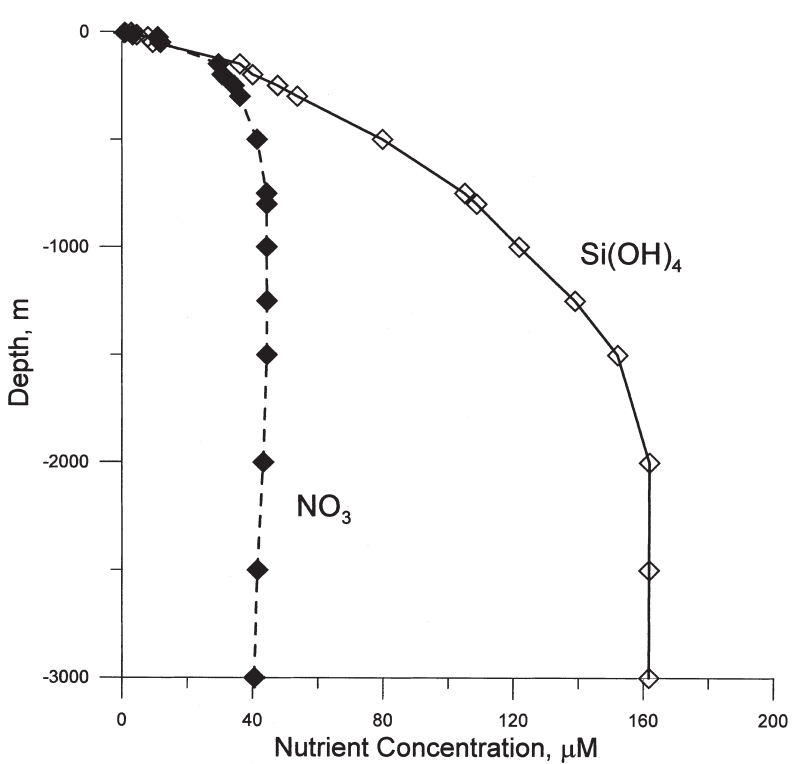

FIG. 1 - Vertical distribution in the Pacific Ocean of $\mathrm{NO}_{3}$ and $\mathrm{Si}(\mathrm{OH})_{4}$ $\left(\mathrm{mmol} \mathrm{m}^{-3}\right)$ measured off the California coast, USA, June 2000 (station A8) during CoOP WEST (http://ccs.ucsd.edu/coop/west/) cruise.

mainly in the upper portion of the water column, usually within the euphotic zone. $\mathrm{NH}_{4}$ escaping to depth is oxidized to $\mathrm{NO}_{3}$ and so is nearly undetectable in most subsurface waters. The concept of fractionation of nitrogen into new and regenerated forms, and the use of ${ }^{15} \mathrm{~N}$ labeled tracers, made it possible to identify the primary production based on new nitrogen sources (new production) and on regenerated nitrogen (regenerated production) (Dugdale and Goering, 1967). The utility of the concept lies in the value of new production setting the upper limit for loss rates, e.g. export production or sedimentation (Eppley and Peterson, 1979) and yield to

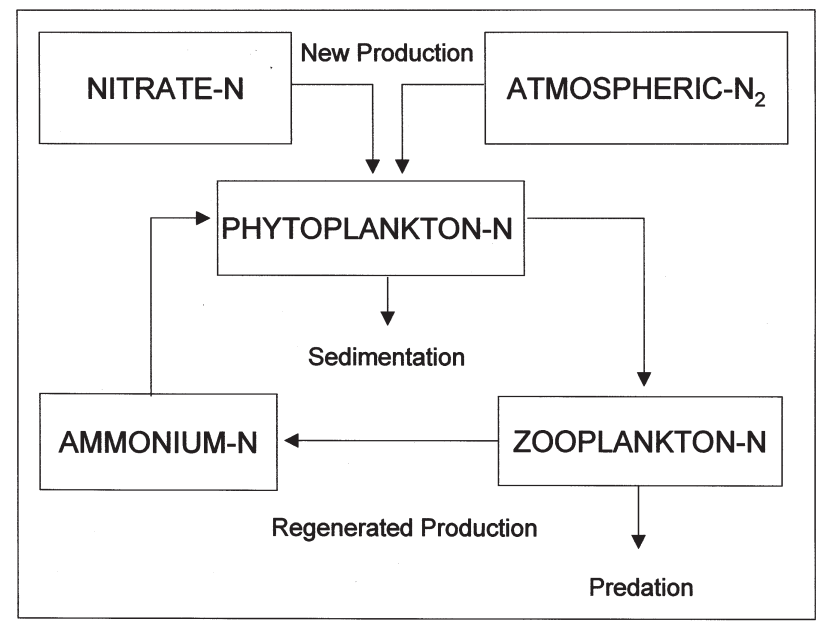

FIG. 2 - Schematic diagram of the oceanic nitrogen production and regeneration cycle. 


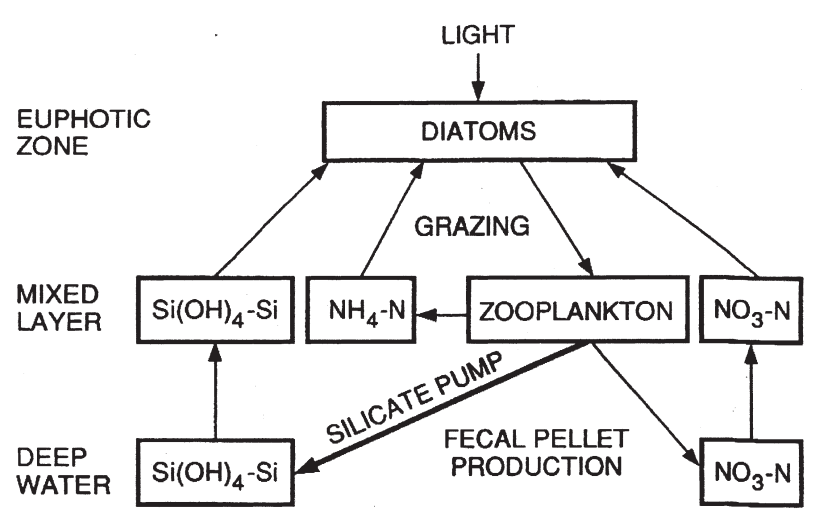

FIG. 3 - Schematic diagram of flow of nitrogen and silicon ( $\mathrm{Si}$ pump) in a diatom-containing oceanic ecosystem (taken from Dugdale et al., 1995).

higher trophic levels (predation). The proportion of new to total $\mathrm{N}$ production (the $f$-ratio) varies widely, from about 0.1 in oligotrophic systems to 0.8 or more in eutrophic conditions (e.g. Dugdale and Wilkerson, 1991, 1992).

\section{LOW Si(OH) $)_{4}$-HIGH $\mathrm{NO}_{3}$ LOW CHLOROPHYLL AREAS}

Since diatoms typically dominate new production (Goldman, 1988), a Si pathway was added to the new and regenerated nitrogen model, based on the premise that $\mathrm{Si}$ re-dissolution occurs below the euphotic zone. In the Si-pump model (Fig. 3) (Dugdale et al., 1995), no regenerated Si pool is allowed in the euphotic zone. Si is taken up by $\mathrm{Si}(\mathrm{OH})_{4^{-}}$ users, primarily diatoms, and exported through sinking of cells or fecal pellet formation and sinking. In this model all $\mathrm{Si}(\mathrm{OH})_{4}$ uptake is new production and

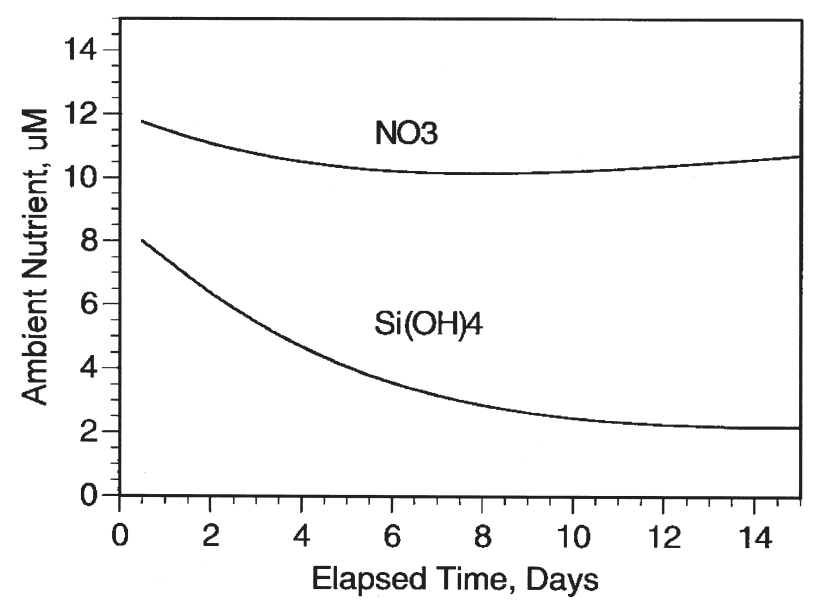

FIG. 4 - Time series of $\mathrm{NO}_{3}$ and $\mathrm{Si}(\mathrm{OH})_{4}$ concentrations $\left(\mathrm{mmol} . \mathrm{m}^{-3}\right)$ in the mixed layer predicted by a simple Si-pump model (taken from Dugdale et al., 1995). available for export. The assumption of zero re-dissolution in the euphotic zone is not strictly true, but the general condition, that $\mathrm{Si}$ regeneration in the euphotic zone is slower than for nitrogen or phosphorus is certainly correct in most circumstances. Application of this simple model to a continuous upwelling system showed that with time, such systems are driven into Si limitation (Fig. 4) (Dugdale et al., 1995). The principle is simple, new nitrogen $\left(\mathrm{NO}_{3}\right)$ gets used more than once through regeneration, $\mathrm{Si}$ is used only once before being exported.

Some ocean systems have been described as productivity paradoxes, in that measurable nutrients are observed with little response by the phytoplankton and resulting in low chlorophyll concentrations. However, these areas, first designated as high nutrient, low chlorophyll (HNLC) areas by Minas et al. (1986), although exhibiting unused $\mathrm{NO}_{3}$, often were even lower in $\mathrm{Si}(\mathrm{OH})_{4}$, suggesting these areas were $\mathrm{Si}(\mathrm{OH})_{4}$ limited for diatoms. Some of these areas were re-designated as low silicate-HNLC (Dugdale and Wilkerson, 1998) and included the Southern Ocean in the region of the polar front, the region between the Peru/Ecuador coast and the Galapagos Islands, and the Eastern Equatorial Pacific (EEP) (Dugdale et al., 1995). The basis for this $\mathrm{Si}\left(\mathrm{OH}_{4}\right)$ limited situation is likely the Si-pump mechanism described above.

\section{THE Si-PUMP IN THE EASTERN EQUATORIAL PACIFIC UPWELLING ECOSYSTEM}

Upwelling occurs (in the EEP) more or less continuously in a narrow band about 1 degree north and south of the equator driven by the trade winds, with some seasonal changes in intensity (Philander, 1990). Nutrient concentrations are easily detectable in the euphotic layer, $\mathrm{NO}_{3} \approx 5 \mathrm{mmol} . \mathrm{m}^{-3}, \mathrm{Si}(\mathrm{OH})_{4}$ about 2 mmol. $\mathrm{m}^{-3}$ and $\mathrm{NH}_{4} \approx 0.1 \mathrm{mmol} . \mathrm{m}^{-3}$ (e.g. Peña et al., 1990; Barber and Chavez, 1991). Chlorophyll concentrations are $\approx 0.1 \mathrm{mg} \mathrm{m}^{-3}$. New production has been measured using ${ }^{15} \mathrm{NO}_{3}$ at $\approx 0.8$ $3.0 \mathrm{mmol} \mathrm{N} \mathrm{m} \mathrm{d}^{-2} \mathrm{~d}^{-1}\left(5-20 \mathrm{mmol} \mathrm{C} \mathrm{m}^{-2} \mathrm{~d}^{-1}\right)$, with measured $f$ values about 0.1 to 0.2 , (e.g, Dugdale et al., 1992; McCarthy et al., 1996) indicating that most primary production is based on regenerated nutrient supply. Growth rates of the phytoplankton are rapid, approaching one doubling per day (Cullen et al., 1992). The paradox of the equator is the presence of nutrient in surface waters and the low phytoplankton biomass (Barber, 1992). Walsh (1976) was the first 
to suggest that grazing controlled the biomass of this ecosystem and Frost and Franzen (1992) incorporated grazing into an equatorial chemostat like model. Grazing was incorporated as the major loss rate since the growth rate of phytoplankton calculated from the physical dilution rate (as in a classical chemostat) gave unrealistically low values at variance with measured growth rates (see below). Lack of iron $(\mathrm{Fe})$ was suggested as the agent of low biomass and new production also but has not proved to be the primary cause as will be discussed below.

$\mathrm{Si}(\mathrm{OH})_{4}$ limitation was implicated by $\mathrm{Ku}$ et al. (1995). Using ${ }^{228} \mathrm{Ra}$, they computed the vertical flux of $\mathrm{Si}(\mathrm{OH})_{4}$ to the upwelling zone of the EEP and concluded that diatoms would be Si limited in that ecosystem. Although the equatorial Pacific phytoplankton biomass was known to be dominated by picoplankton (Chavez et al., 1996) a strong role for diatoms in equatorial new production was indicated by a plot of $\mathrm{NO}_{3}$ vs. $\mathrm{Si}(\mathrm{OH})_{4}$ for data from $140^{\circ} \mathrm{W}$, $0.5^{\circ} \mathrm{N}$ with a slope of $1: 1$ (Dugdale and Wilkerson, 1998). Landry et al. (1997) found a very strong correlation between diatom chlorophyll and ${ }^{15} \mathrm{NO}_{3}$ uptake in the EEP during US JGOFS (Joint Global Ocean Flux Studies). However, measured $f$ values for the equatorial Pacific upwelling were low, 0.1 to 0.2 and to accommodate this information and the known biomass dominance of the picoplankton, a model based upon the Si-pump model was proposed in which the $\mathrm{NO}_{3}$ was taken up by the diatoms and the $\mathrm{NH}_{4}$ arising from grazing on diatoms was taken up by the picoplankton (Dugdale and Wilkerson, 1998). This idea was not very popular since it was already known that some picoplankton, e.g cultured isolates were capable of $\mathrm{NO}_{3}$ uptake as well as $\mathrm{NH}_{4}$, and it turned out that the $1: 1 \mathrm{Si}: \mathrm{NO}_{3}$ slope used to fit the model was an extreme case and a wide range of $\mathrm{Si}: \mathrm{NO}_{3}$ slopes could be observed in the equatorial system (Dunne et al., 1999). Recent work suggests that $\mathrm{NO}_{3}$ assimilation may not be universal in all picoplankton and the gene for $\mathrm{NO}_{3}$ assimilation may be lacking in some Synechococcus and Prochloroccocus species (Zehr, pers com.) Nevertheless, this simple model was a step on the way to the development of a more realistic equatorial productivity model.

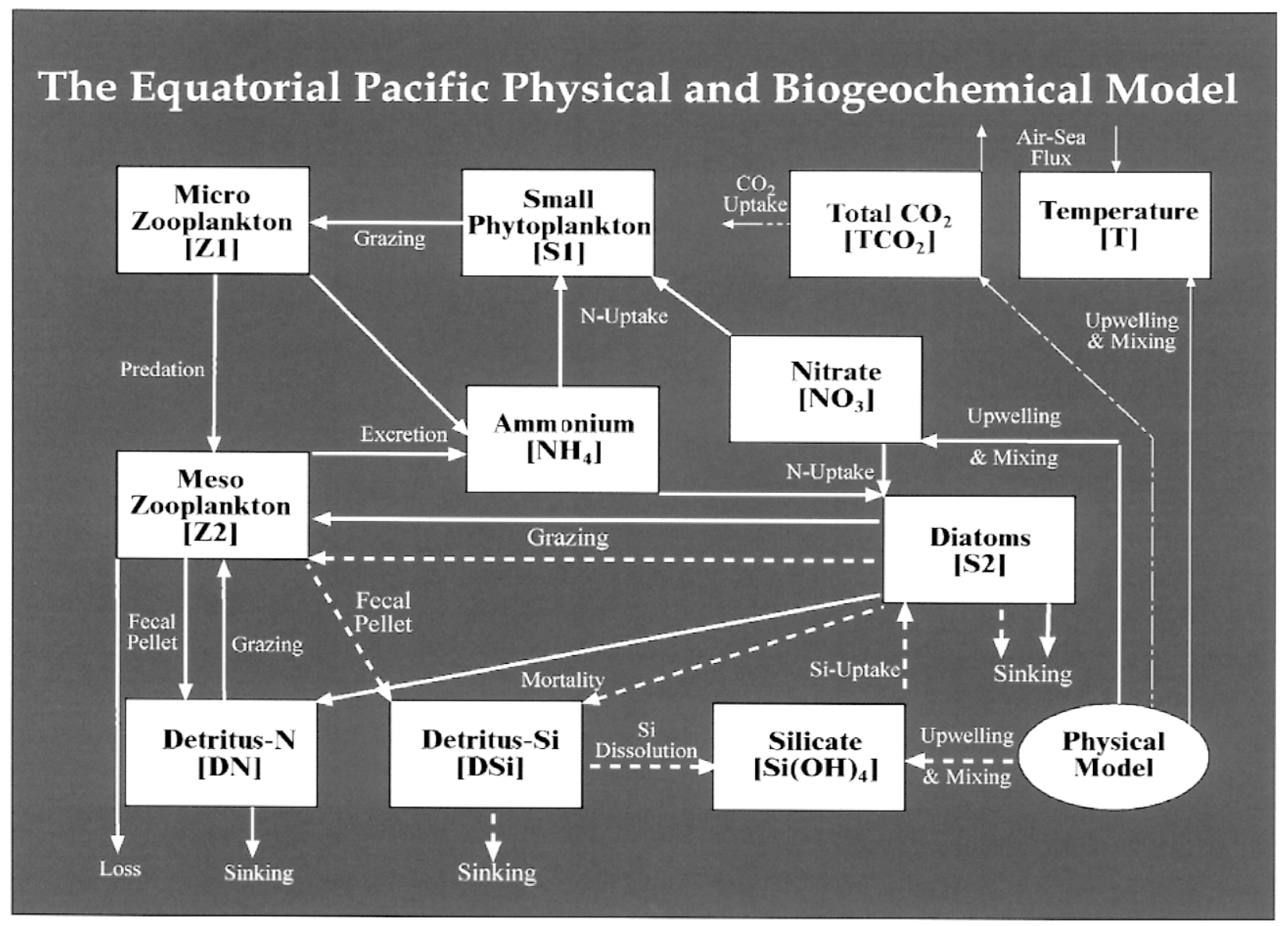

FIG. 5 - The inter-compartmental flow diagram of the 1-D model for the EEP (taken from Chai et al., in press). 


\section{EVOLUTION OF MODELS FOR THE EEP INCORPORATING THE Si-PUMP}

A one dimensional (1-D) model of the equatorial Pacific upwelling system (Fig. 5) (Chai et al., in press) was then constructed by adding the Si-pump to the model of the EEP ecosystem of Chai et al. (1996). The essential features include incorporation of two phytoplankton components (diatoms and picoplankton, i.e. $\mathrm{Si}(\mathrm{OH})_{4}$ and non $\mathrm{Si}(\mathrm{OH})_{4}$-users) three macro-nutrients, $\mathrm{NO}_{3}, \mathrm{NH}_{4}$, and $\mathrm{Si}(\mathrm{OH})_{4}, \mathrm{Fe}$ as an indirect effect on photosynthesis, and two sizes of zooplankton (microzooplankton and mesozooplankton). Both fractions of the phytoplankton use $\mathrm{NO}_{3}$ and $\mathrm{NH}_{4}$, only diatoms use $\mathrm{Si}(\mathrm{OH})_{4}$ which is not regenerated in the model (a procedure justified by a sensitivity analysis that showed only very low regeneration values gave reasonable steady state solutions; Dugdale et al., in press a). The model was initialized with mean nutrients from Levitus et al. (1993) at $120 \mathrm{~m}$ for the Wyrtki box $\left(90-180^{\circ} \mathrm{W}, 5^{\circ} \mathrm{N}-5^{\circ} \mathrm{S}\right)$ and with rate constants and biomass from the literature (Chai et al., in press). The model is very stable and steady state values are generally close to observations, as shown in the model and field data from JGOFS cruise TT011 (Murray et al. 1995), describing the vertical distribution of $\mathrm{Si}(\mathrm{OH})_{4}$ and $\mathrm{NO}_{3}$ (Fig. $6)$. The surface $\mathrm{Si}(\mathrm{OH})_{4}$ concentration, about 3 mmol. $\mathrm{m}^{-3}$ is about half that of $\mathrm{NO}_{3}$ and the shapes of the curves from data are reproduced faithfully by the model. At the source depth of nutrients for the model $(120 \mathrm{~m}) \mathrm{Si}(\mathrm{OH})_{4}$ concentrations are lower than for $\mathrm{NO}_{3}$, a condition that would lead to Si limitation of diatoms in a conventional chemostat. However, both the model and the equatorial ecosystem are not exactly equivalent to a conventional chemostat since a mixture of $\mathrm{Si}(\mathrm{OH})_{4}$-using algae and non $\mathrm{Si}(\mathrm{OH})_{4}{ }_{-}$ users are present, and the loss rates are dominated not by dilution but by grazing of zooplankton.

\section{ACHIEVEMENT OF STEADY STATE IN A CONVENTIONAL CHEMOSTAT}

Steady state in a conventional chemostat is achieved through the interaction of loss rates and the nutrient uptake kinetics of the organism being continuously cultured. The loss rate (= dilution rate, D) is set by the experimenter by manipulating the flow rate of the nutrient mixture designed to assure limitation of a particular nutrient $(\mathrm{F})$ or the volume of the reactor or culture vessel $(\mathrm{V})$ :

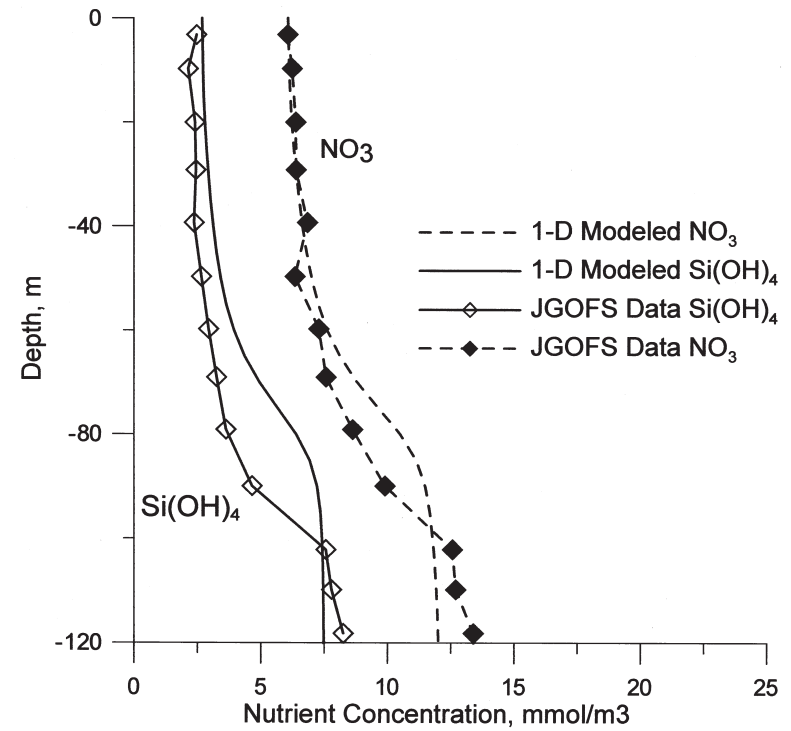

FIG. 6 - Comparison of $\mathrm{NO}_{3}$ and $\mathrm{Si}(\mathrm{OH})_{4}$ concentrations from the 1-D model (no symbols) and observed data from JGOFS TT011 cruise (Murray et al., 1995) from $2.5^{\circ} \mathrm{N}$ (with symbols).

$$
\mathrm{D}=\mu=\mathrm{F} / \mathrm{V}
$$

where $\mu$ is growth rate. Provided the maximum growth rate of the organism is not exceeded by the value of $\mathrm{D}$, regulation occurs usually through the Michaelis-Menten equation:

$$
\mathrm{V}=\mathrm{V}_{\max } * \mathrm{~S} /\left(\mathrm{K}_{\mathrm{S}}+\mathrm{S}\right)
$$

where $\mathrm{S}$ is the concentration of the limiting nutrient and $\mathrm{K}_{\mathrm{S}}$ is the half-saturation concentration, i.e. the concentration at which the value of $\mathrm{V}=1 / 2 \mathrm{~V}_{\max }$. The value of $\mathrm{D}$ selected by the experimenter sets the steady state value of $S$ and the difference between $S$ and the concentration of the limiting nutrient in the feed, $S_{f}$, determines the biomass (B) of the organism in the reactor:

$$
\mathrm{B}=\left(\mathrm{S}_{\mathrm{f}}-\mathrm{S}\right)
$$

or as cell numbers:

$$
\mathrm{P}=\left(\mathrm{S}_{\mathrm{f}}-\mathrm{S}\right) / \mathrm{Q}
$$

where $\mathrm{Q}$ is the concentration of limiting nutrient per cell. The negative feedback mechanism forcing steady state is through the biomass in the reactor. If the biomass exceeds the steady state value, the concentration of the limiting nutrient decreases below the steady state point and the growth rate is reduced until the concentration of $\mathrm{S}$ in the reactor increases and the 
growth rate is again at steady state. A complication in chemostat culture of some algae occurs when the cell quota is reduced at low growth rates, tending to maximize the number of cells (e.g. Droop, 1974; Davis et $a l ., 1978)$. The effect of a reduced cell quota was considered by Dugdale (1976) and can be detected as an increase of $\mathrm{V}_{\text {max }}$. When appliying chemostat theory to the EEP as a Si-limited system, the effect will be ignored as the kinetics of $\mathrm{Si}$ uptake measured on the equator (Leynaert et al., 2001) appear to be unmodified by a variable quota effect.

\section{ACHIEVEMENT OF STEADY STATE IN THE 1-D EQUATORIAL MODEL}

A sensitivity analysis of the 1-D model for the EEP to changes in source $\mathrm{Si}(\mathrm{OH})_{4}$ showed the diatom population to be limited by $\mathrm{Si}$, the $\mathrm{Si}(\mathrm{OH})_{4}$ concentration varying around a steady state value depending on the loss rate which in turn sets the growth rate. This is appropriate as in the 1-D model $\mathrm{Si}(\mathrm{OH})_{4}$ uptake follows the Michaelis-Menten equation with a $\mathrm{K}_{\mathrm{S}}$ of $3.0 \mathrm{mmol} . \mathrm{m}^{-3}$. The range of $\mathrm{V}_{\mathrm{Si}}$ in the model $\left(0.5\right.$ to $\left.0.8 \mathrm{~d}^{-1}\right)$ with the source $\mathrm{Si}$ concentration varied from 3 to $15 \mathrm{mmol} . \mathrm{m}^{-3}$ reflects the values of the loss rates for the diatom population and the diatom growth rate, assuming steady state. This value is to be compared with the dilution rate, equivalent to the upwelling rate of $1 \mathrm{~m} . \mathrm{d}^{-1}$ divided by the depth of the mixed layer $(60 \mathrm{~m})$, which equals $0.014 \mathrm{~d}^{-1}$, very low compared to the $\mathrm{V}_{\mathrm{Si}}$ values, and shows the dilution model for loss is incorrect for this system. In the 1-D model, specific loss rates due to zooplankton grazing range from 0.45 to $1.1 \mathrm{~d}^{-1}$ indicating that the major loss in the EEP is grazing, not dilution. The main point to be understood for a chemostat-like system such as the equatorial Pacific upwelling is that the loss rate sets the steady state growth rate which in turn requires a specific $\mathrm{Si}(\mathrm{OH})_{4}$ ambient concentration to achieve a balance between loss and growth. This concept is frequently not understood and for example, the question has been asked "why isn't all of the $\mathrm{Si}(\mathrm{OH})_{4}$ used up if $\mathrm{Si}(\mathrm{OH})_{4}$ is the limiting nutrient?" The answer is that the Michaelis-Menten relationship requires a finite amount of substrate to drive the uptake reaction at the level set by the loss rate. This is somewhat counter-intuitive and requires thinking about the system from the loss end rather than from the growth end.
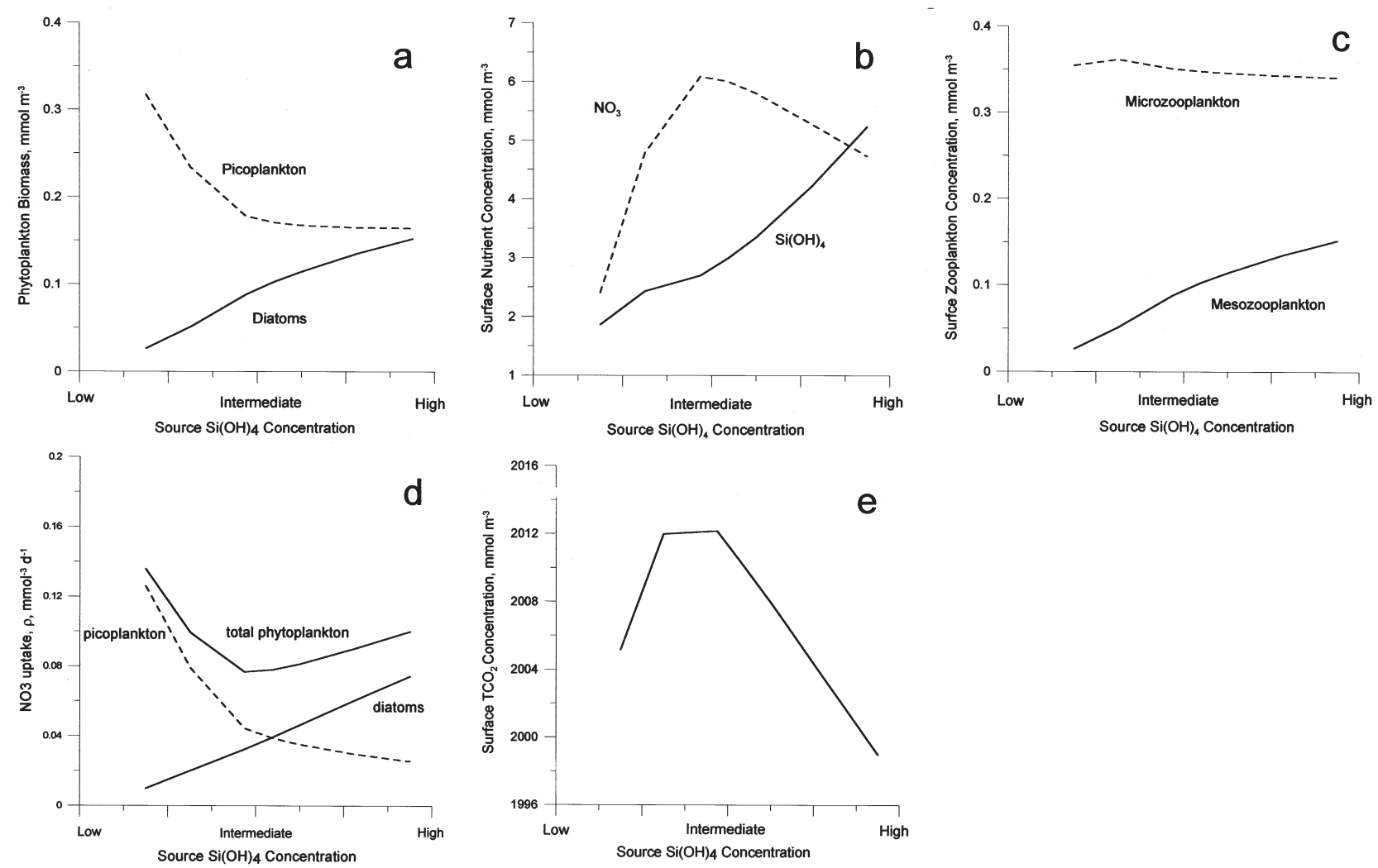

FIG. 7 - Surface response of the 1-D model to changes in source $\mathrm{Si}(\mathrm{OH})_{4}$ concentration, a) phytoplankton biomass $\left(\mathrm{mmol} \mathrm{m}^{-3}\right)$, b) nutrient concentrations $\left(\mathrm{mmol} \mathrm{m}^{-3}\right)$, c) zooplankton biomass, $\left(\mathrm{mmol} \mathrm{m}^{-3}\right)$, d) $\mathrm{NO}_{3}$ uptake $\left(\mathrm{mmol} \mathrm{m}^{-3} \mathrm{~d}^{-1}\right)$, e) $\mathrm{TCO}_{2}\left(\mathrm{mmol} \mathrm{m}^{-3}\right)$. 


\section{IMPORTANCE OF $\mathrm{Si}(\mathrm{OH})_{4}$ SUPPLY ON DIATOM COMPETITION IN THE EEP}

The functioning of this complex ecosystem 1-D model for the EEP can be discerned from Figure 7 illustrating changes resulting from varying the source $\mathrm{Si}(\mathrm{OH})_{4}$ concentration from low to high (3 to $15 \mathrm{mmol} . \mathrm{m}^{-3}$ ) holding $\mathrm{NO}_{3}$ concentration constant at $12 \mathrm{mmol} . \mathrm{m}^{-3}$. The interaction between diatoms and picoplankton is one of the interesting features of the 1-D model results. As source $\mathrm{Si}(\mathrm{OH})_{4}$ increases, diatoms increase in biomass as expected, but the picoplankton decrease strongly and then remain at a lower concentration (Fig. 7a). Ambient $\mathrm{Si}(\mathrm{OH})_{4}$ increases (Fig 7b) in response to increased mesozooplankton grazing on diatoms (Fig. $7 \mathrm{c}$ ). $\mathrm{NH}_{4}$ concentration increases due to enhanced mesozooplankton grazing and nitrogen regeneration. $\mathrm{NO}_{3}$ concentration increases initially, due to the decreased $\mathrm{NO}_{3}$ uptake by the picoplankton - a result of inhibition by $\mathrm{NH}_{4}$ - then decreases as source $\mathrm{Si}(\mathrm{OH})_{4}$ exceeds the intermediate range $\left(7.5 \mathrm{mmol} . \mathrm{m}^{-3}\right)$ as the diatom population increases. The decrease in picoplankton $\mathrm{NO}_{3}$ uptake that occurs as source $\mathrm{Si}(\mathrm{OH})_{4}$ increases from low to intermediate range, results in a decrease in total phytoplankton $\mathrm{NO}_{3}$ uptake (Fig. 7d). An important consequence of the apparent suppression of picoplankton by an increasing diatom population is the bell shaped $\mathrm{TCO}_{2}$ vs. source $\mathrm{Si}(\mathrm{OH})_{4}$ concentration (Fig. 7e) due to the link between carbon uptake and $\mathrm{NO}_{3}$ uptake. A maximum in surface $\mathrm{TCO}_{2}$ occurs at intermediate source $\mathrm{Si}(\mathrm{OH})_{4}$ concentrations (Fig 7e), whereas $\mathrm{TCO}_{2}$ is reduced at higher source $\mathrm{Si}(\mathrm{OH})_{4}$ concentrations as diatoms increase. Whether this 1-D model result occurs in nature is unresolved at present. An alternative to the hypothesis that diatoms directly impact picoplankton populations is that the picoplankton remain constant and only diatoms and other phytoplankton change in biomass (Le Borgne, pers comm.).

Coccolithophorids incorporate carbon from $\mathrm{CO}_{2}$ to form soft parts as do other phytoplankton, but also take up bicarbonate to form their carbonate (calcite) shells. The incorporation of carbon for soft parts reduces the $\mathrm{TCO}_{2}$, but the formation of calcite results through reduced alkalinity (from withdrawal of calcium ions) in an increase in $\mathrm{CO}_{2}$ such that the final result is that $\mathrm{pCO}_{2}$ increases as a result of cocolithophorid growth. Since diatoms, however, reduce $\mathrm{TCO}_{2}$ and $\mathrm{pCO}_{2}$ directly, the proportion of primary production accomplished by diatoms compared to coccolithophorids has the potential to influ- ence strongly the marine carbon cycle. Consequently, understanding the factors that control the relative success of these two functional groups of phytoplankton is central to understanding the role of biology in the carbon processes of the ocean. Harrison (2000) has proposed that changes in $\mathrm{Si}(\mathrm{OH})_{4}$ supply by influencing the relative success of diatoms and coccolithophorids may have been a key to glacial/interglacial transitions. Mesocosm experiments conducted with semi-continuous nutrient additions showed that a coccolithophore, Emiliania huxleyi, and other picoplankton as well, are unable to compete with diatoms when $\mathrm{Si}(\mathrm{OH})_{4}$ concentrations are above about $2 \mathrm{mmol} . \mathrm{m}^{-3}$ and $\mathrm{PO}_{4}$ and $\mathrm{NO}_{3}$ are present in non-limiting concentrations (Egge and Aksnes, 1992), and formed the basis for an ecosystem model using three functional groups of phytoplankton (Aksnes et al., 1994).

\section{THE ROLE OF IRON IN Si LIMITATION OF DIATOMS}

Micronutrients may influence the $\mathrm{Si}(\mathrm{OH})_{4}$ limitation (Si-limited chemostat scenario) for EEP diatoms. Iron is necessary for many cell processes and it may be difficult to isolate the exact sites of $\mathrm{Fe}$ limitation in natural populations. However, virtually all $\mathrm{Fe}$ enrichments show strong effects on diatom growth. The most likely effect of micronutrients on any phytoplankton process was suggested to be on the production of the amount of enzyme for whatever process is being catalyzed and consequently would be expressed in the value of $\mathrm{V}_{\max }$ in the Michaelis-Menten equation (Dugdale, 1967). Regulation in a continuous culture system would still occur on the primary limiting nutrient (for example $\mathrm{Si}(\mathrm{OH})_{4}$ in the EEP), so that with a constant loss rate, the variation observed would be in the ambient concentration of the limiting nutrient and the biomass of the cultured organism. Fe is upwelled in the EEP along with the primary nutrients including $\mathrm{Si}(\mathrm{OH})_{4}$ (Landry et al., 1997), and considering the high growth rates of both diatoms and picoplankton there does not seem to be a clear limitation by Fe; however the kinetic experiments that would reveal a co-limitation by $\mathrm{Fe}$ and $\mathrm{Si}$ have not been made in the EEP.

Enrichment experiments showed Fe to stimulate phytoplankton growth especially diatoms, in the equatorial Pacific (IronEx-1, Martin et al., 1994; IronEx-2, Coale et al., 1996). However, these exper- 
iments were made outside the upwelling areas. In our 1-D model for the EEP, we do not include Fe as a limiting nutrient explicitly, but rather consider it's role implicitly through the parameters that determine the growth rate of diatoms. There are two parameters in our current model reflecting Fe limitation, alpha, $\alpha$, the slope of the photosynthetic rate over irradiance at low irradiance, and $\mathrm{K}_{\mathrm{Si}(\mathrm{OH})_{4}}$, the halfsaturation for $\mathrm{Si}(\mathrm{OH})_{4}$ uptake which varies considerably (Nelson and Brzezinski, 1990; Nelson and Treguer, 1992). When the model was run to mimic an $\mathrm{Fe}$ enrichment experiment ecological behaviors similar to these observed during the field Fe enrichment experiments (Martin et al., 1994; Coale et al., 1996; Boyd et al., 2000) resulted (Chai et al., in press).

\section{THE SIGNIFICANCE AND CAUSE OF LOW SOURCE $\mathrm{Si}(\mathrm{OH})_{4}$ CONCENTRATIONS}

The importance of the low $\mathrm{Si}(\mathrm{OH})_{4}$ condition of the equatorial Pacific upwelling system arises from the control of diatom processes especially new carbon and carbon export production. A major role for the equatorial Pacific in the global ocean/atmospheric $\mathrm{CO}_{2}$ exchange has been established by the observation that during El Niño events $\mathrm{CO}_{2}$ efflux from the equator falls to virtually zero and the rise in atmospheric $\mathrm{CO}_{2}$ is reduced or disappears. The 1-D model results suggest that there may be changes in $\mathrm{TCO}_{2}$ at the equator linked to changes in upwelling source $\mathrm{Si}(\mathrm{OH})_{4}$ concentrations.

The low $\mathrm{Si}(\mathrm{OH})_{4}$ condition of the source waters for equatorial upwelling, first noted by $\mathrm{Ku}$ et al. (1995) is of southern origin. Sections of nutrients across the equator show a strong asymmetry, e.g. (e.g. Carr et al., 1992, their Fig 5) with isopleths sloping more steeply to the south than to the north. At the equator, the source of upwelling water to the surface is from the upper part of the Equatorial Undercurrent (EUC) originating in the far western Pacific and flowing at depths of 100 to $300 \mathrm{~m}$ across to the eastern Pacific boundary. The current system in the western Pacific where the EUC originates is complex, (Fig. 8) (Fine et al., 1994). The northern source of water is the Mindanao Current and the southern source is the New Guinea Coastal Undercurrent (NGCUC). Following the approach of Toggweiler and Carson (1995) for $\mathrm{NO}_{3}$ the fluxes of $\mathrm{Si}(\mathrm{OH})_{4}$ and $\mathrm{NO}_{3}$ were calculated for the north and south sources (Dugdale et al., in press b), and showed both sources for $\mathrm{NO}_{3}$ to be about equal. However, only $30 \%$ of the total $\mathrm{Si}(\mathrm{OH})_{4}$ supply was from the south, i.e. the $\mathrm{Si}(\mathrm{OH})_{4}: \mathrm{NO}_{3}$ ratio was about 0.7 in the NGCUC compared to 1:1 for the northern source water for the EUC. Consequently the mixture of the two waters as the EUC is formed is lower in

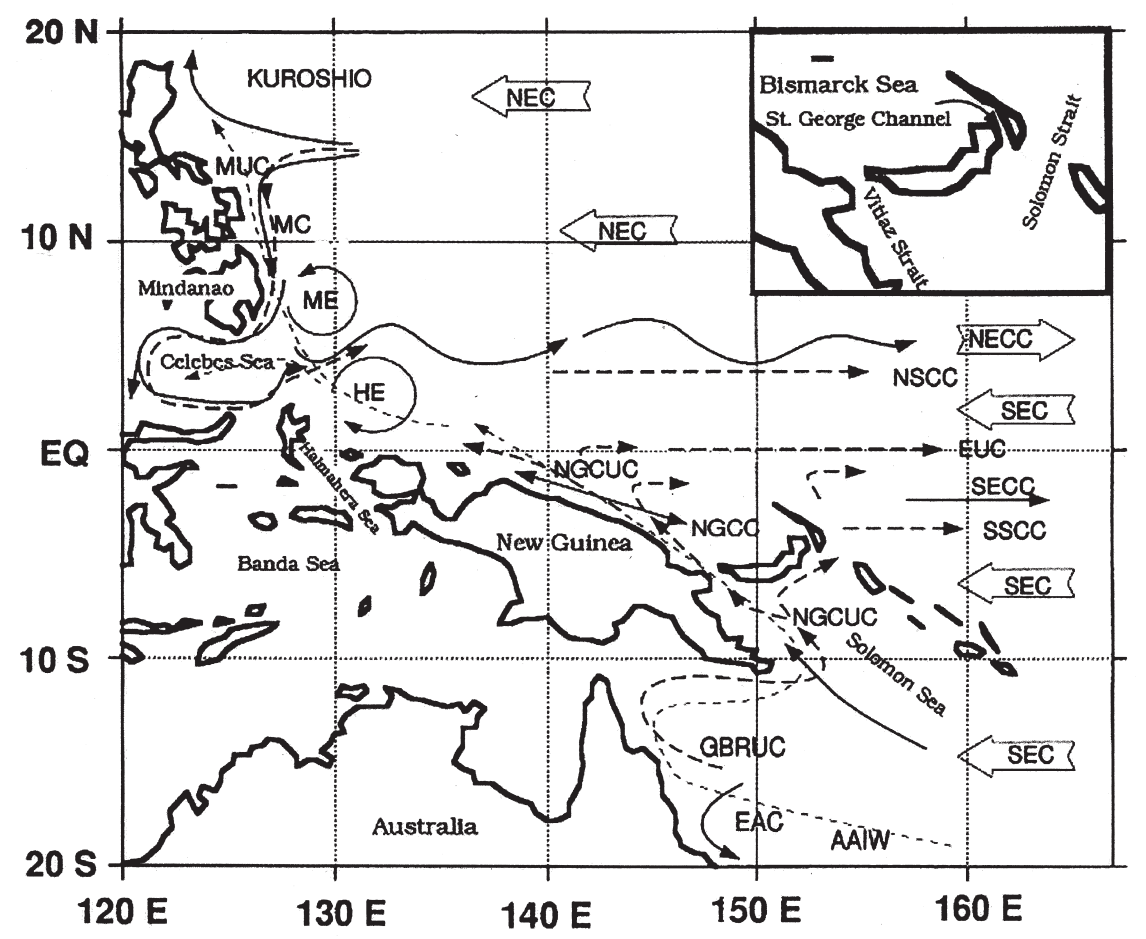

FIG. 8 - Current system of the western equatorial Pacific (from Fine et al., 1994). 


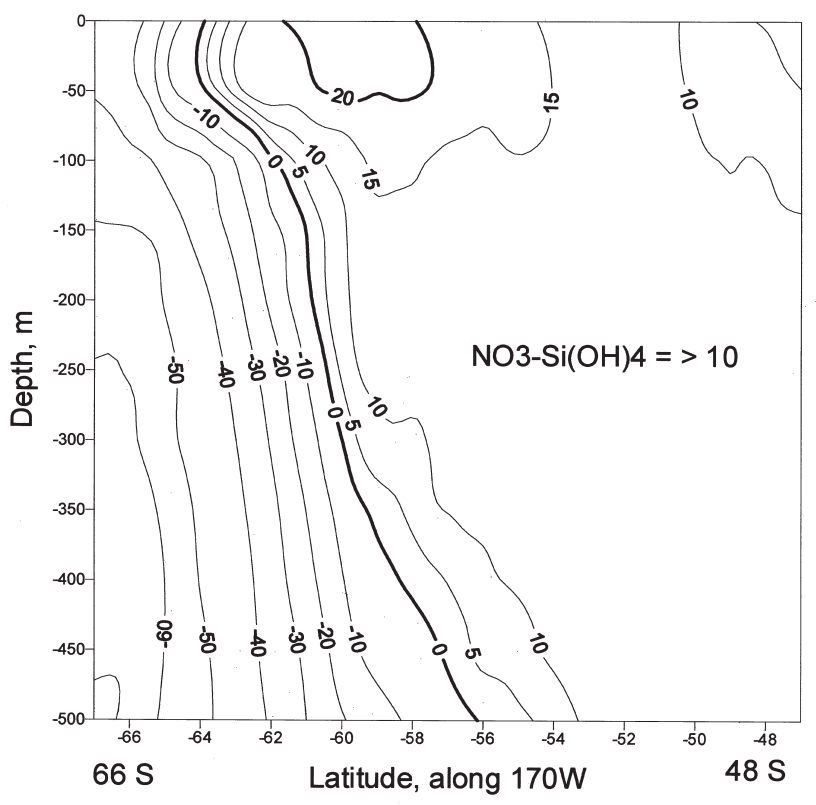

FIG. 9 - Values of $\mathrm{NO}_{3}-\mathrm{Si}(\mathrm{OH})_{4}$ at $170^{\circ} \mathrm{W}, 48^{\circ}-66^{\circ} \mathrm{S}$, calculated from WOCE (World Ocean Circulation Experiment) nutrient data measured during cruise $\mathrm{p} 15 \mathrm{~s}$.

$\mathrm{Si}(\mathrm{OH})_{4}$ compared to $\mathrm{NO}_{3}$ and since the average composition of diatoms occurs in the $\mathrm{Si}: \mathrm{N}$ ratio of 1:1 (Brzezinski, 1985), the composition of the EUC assures the Si limitation of equatorial diatoms in the upwelling region.

The cause of Si limitation in the equatorial Pacific is to be found far to the south, in the Southern Ocean where SubAntarctic Mode Water (SAMW), the source water for the NGCUC, is formed at and to the north of the Polar Front (PF) (Tsuchiya, 1991). Although it has been known for some time that surface waters north of the $\mathrm{PF}$ are low in $\mathrm{Si}(\mathrm{OH})_{4}$ but high in $\mathrm{NO}_{3}$ (Broecker and Peng, 1982), the process resulting in this distribution has only become clear recently from JGOFS studies of the US and other countries, especially of France. During austral winter, deep mixing results in high concentrations of nutrients in the mixed layer to the south of the PF. In spring, with light and stratification, a diatom bloom begins near the PF and develops in a southerly direction, taking up $\mathrm{Si}(\mathrm{OH})_{4}$ at high rates, but $\mathrm{NO}_{3}$ and carbon at low rates, leaving behind water low in $\mathrm{Si}(\mathrm{OH})_{4}$ and high in $\mathrm{NO}_{3}$ (Nelson et al., in press; Pondaven et al. (2000). The depletion of $\mathrm{Si}\left(\mathrm{OH}_{4}\right)$ relative to $\mathrm{NO}_{3}$ is a factor of 4 or more in this production system, an extreme example of the Si-pump. A circumpolar band of siliceous sediment is the result. This water moves northward first in an easterly direction and then westerly into the NGCUC and to the EUC. The deficiency in south Pacific water is apparent in Figure 9 (WOCE data) where the $\mathrm{Si}(\mathrm{OH})_{4}$ concentrations have been subtracted from the $\mathrm{NO}_{3}$ values. With diatom requirements for Si:N of about $1: 1$, the contours indicate the magnitude of the Si deficiency in this water for the support of diatom populations, e.g. values for $\mathrm{NO}_{3}$ minus $\mathrm{Si}(\mathrm{OH})_{4}$ of up to 20 (Fig. 9).

Another source of $\mathrm{Si}(\mathrm{OH})_{4}$ to the equatorial ecosystem is the rivers of the western equatorial Pacific which provide up to $20 \%$ of the sediment load to the ocean (Milliman et al., 1999). Rivers typically have very high $\mathrm{Si}(\mathrm{OH})_{4}$ concentrations, 200 mmol. $\mathrm{m}^{-3}$ or greater and during normal, non-El Niño years must provide a substantial amount of $\mathrm{Si}(\mathrm{OH})_{4}$ to the nearby ocean, for example, in the section shown in Figure 10, from the coast of New Guinea to $10^{\circ} \mathrm{N}$, a surface layer of low salinity, enhanced $\mathrm{Si}(\mathrm{OH})_{4}$ layer can be seen. The quantitative contribution of $\mathrm{Si}(\mathrm{OH})_{4}$ from this source is at present unknown.

\section{CONNECTIONS BETWEEN THE SOUTHERN OCEAN AND THE EQUATORIAL PACIFIC: IMPLICATIONS FOR PALEOCLIMATOLOGY}

A role for the equatorial Pacific in glacial cycles is suggested by the extraordinary capacity of the Southern Ocean to trap $\mathrm{Si}(\mathrm{OH})_{4}$ that would otherwise be transported north to the equatorial Pacific, and the capacity of diatoms to export carbon to the deep ocean due to their relatively large size (Michaels and Silver, 1988). Comparing the ocean

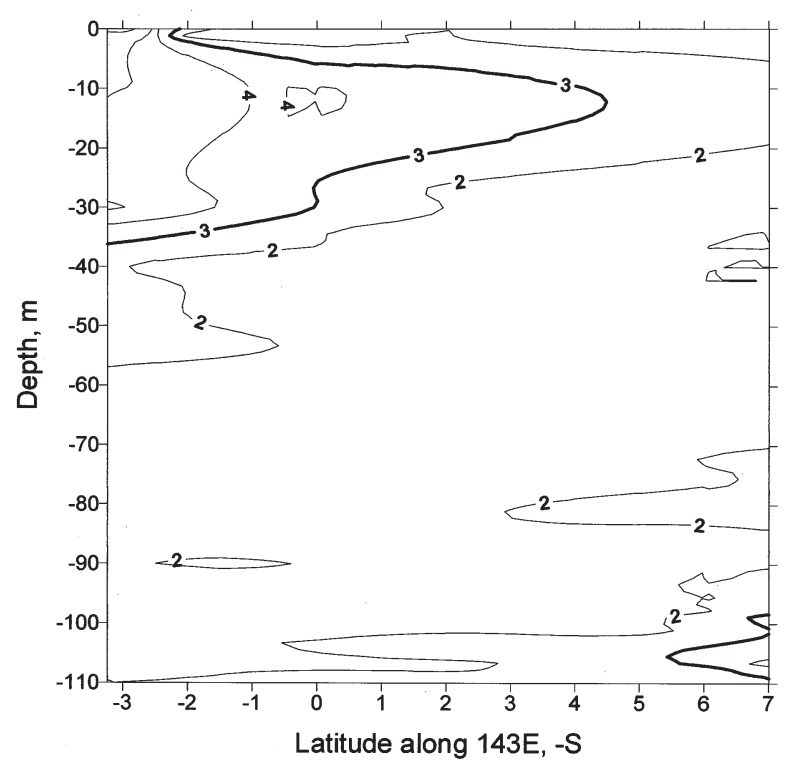

FIG. 10. - Meridional section at $143^{\circ} \mathrm{E}, 3^{\circ} \mathrm{S}-7^{\circ} \mathrm{N}$ of silicate $\left(\mathrm{mmol} \mathrm{m}^{-3}\right)$ from WEPOCS III data (Lukas et al., 1991). 
sediment distribution of $\mathrm{Si}$ with surface ocean $\mathrm{pCO}_{2}$ suggests such a connection; the two major areas of high sediment $\mathrm{Si}$ are the Southern Ocean and the equatorial Pacific. The equatorial Pacific is the major oceanic source of $\mathrm{CO}_{2}$ to the atmosphere. Paleoceanographers and paleoclimatologists have been searching for a long-period (long time scale) feedback system to explain the correlation between glacial maxima and atmospheric $\mathrm{CO}_{2}$, which tends to fall steadily during ice buildup to values about $170 \mu \mathrm{atm}(100 \mu \mathrm{atm}$ below the preindustrial level of $270 \mu \mathrm{atm})$. Feedback directly through ocean chemistry and current systems to produce changes in new production occur on a time scale that is too short, about 1000 years or a bit less. A feedback with the correct time scale, i.e. tens of thousands of years might occur as the Antarctic ice builds northward, reducing the Southern Ocean trapping of Si. With more $\mathrm{Si}(\mathrm{OH})_{4}$ transported northward to supply the equatorial diatoms, $\mathrm{CO}_{2}$ at the surface ocean would be reduced and atmospheric $\mathrm{CO}_{2}$ would decline, bringing about additional cooling and ice formation. For example, an additional $15 \mathrm{mmol} . \mathrm{m}^{-3} \mathrm{Si}(\mathrm{OH})_{4}$ (to offset the Si deficiency in Fig. 9) transported northward into the equatorial upwelling system would result in a drawdown of $50 \mathrm{mmol} . \mathrm{m}^{-3} \mathrm{TCO}_{2}$. The 50 mmol. $\mathrm{m}^{-3}$ reduction in $\mathrm{TCO}_{2}$ translates to a reduction of $71.5 \mu \mathrm{atm} \mathrm{pCO}_{2}$ at the ocean surface. Reduced Southern Ocean production in glacial periods is suggested by Charles et al. (1991), Morlock et al. (1991) and Sigman and Boyle (2000) and increased BSi deposition in the central Equatorial Pacific has been shown by Lyle et al. (1988) at glacial maxima.

\section{CONCLUSION}

Diatoms with their fast growth rates and unique relationship to the $\mathrm{Si}$ cycle have the potential for controlling the nutrient and $\mathrm{CO}_{2}$ environment of large important areas of the ocean. The time scales over which these controls or feedback interactions extends from seasonal to El Niño/LaNiña (e.g. in precipitation cycles in the western tropical Pacific) to the glacial/interglacial scale interactions between the Southern Ocean and the equatorial Pacific. Diatom effects may be direct, as in export production of $\mathrm{CO}_{2}$, or indirect through competition or inhibition of other phytoplankton functional groups, e.g. by reduction of picoplankton activity, or by outcompeting coccolithophores.
The broad-based case for such a strong diatom role in global processes rests on analyses of cores by paleoceanographers, on enclosure and shipboard experimentation, and on modeling. Although the 1D model discussed here seem to predict well conditions in the equatorial Pacific upwelling, there are some poorly known, but crucial parameters needed to assess whether we are on the right track and whether the models may be useful in decision making. The modeling exercise opens up a number of questions. Question 1, What is the dissolution rate for $\mathrm{BSi}$ in the equatorial upwelling system, the Southern Ocean, or in most of the ocean for that matter? The techniques to make direct isotopic measurements of this rate in areas of the ocean with low phytoplankton biomass are just becoming available. Question 2, Is there a decrease in picoplankton numbers (concentration) as diatom populations and activity increase? The modeled effect of this interaction between different members of the phytoplankton community is through the $\mathrm{NH}_{4}$ inhibition of $\mathrm{NO}_{3}$ uptake formulation, with increased ambient $\mathrm{NH}_{4}$ supplied through increased grazing fueled by increased diatom biomass. New methods to measure phytoplankton communities rapidly (e.g. HPLC pigment analyses and advances in fllow cytometry). Question 3, Do the picoplankton and the diatoms each have a new and regenerated production cycle, i.e. do both take up both $\mathrm{NO}_{3}$ and $\mathrm{NH}_{4}$, or do the diatoms take up the new nitrogen, $\mathrm{NO}_{3}$, and pass part of it on to the picoplankton that are unable to take up $\mathrm{NO}_{3}$. Marine free living and symbiotic cyanobacteria may use atmospheric $\mathrm{N}_{2}$ as a new $\mathrm{N}$ source (Carpenter, pers. comm). Size-fractionated measurements of $\mathrm{NO}_{3}$ and $\mathrm{NH}_{4}$ uptake may answer that question, and molecular techniques are just now available to assess the genetic capability to reduce $\mathrm{NO}_{3}$ of both prokaryotic and eukaryotic phytoplankton. Question 4, How do $\mathrm{Si}(\mathrm{OH})_{4}$ and Fe limitation act on diatoms in an area such as the equatorial Pacific where both are supplied by upwelling? The clean sampling techniques and suitable isotopes are available to test this effectively. Question 5, Why do some Southern Ocean diatoms have the bizarre composition ratio for $\mathrm{Si}, \mathrm{N}$ and $\mathrm{C}$ ? There are indications that Fe deficiency is the cause (Franck et al., 2000), but any factor that reduces diatom growth rate, e.g. temperature, may have the same effect. An understanding of the factors controlling diatom composition and their variability in the Southern Ocean is crucial to understanding the role of diatoms in trapping so much of the ocean's Si supply and its poten- 
tial role in climate change. Question 6, How can detailed physiological models of phytoplankton growth (e.g. Flynn and Martin-Jezequel, 2000) be incorporated into general circulation models? With the rapid development of super-computing power, adding more compartments and pathways is feasible in near-future oceanographic models.

We biologists have a remarkable opportunity to participate in the quest to understand the role of biology in the grand biogeochemical processes of the earth-ocean system. The diatom-Si story is one of these and whose importance is just beginning to be realized.

\section{ACKNOWLEDGEMENTS}

We wish to thank the National Science Foundation JGOFS-Synthesis and Modeling Program (OCE9802060 to RCD and FPW) and Coastal Ocean Processes Program (OCE-9910898 to RCD and FPW) for financial support, and to SMP investigators for thoughtful discussions at SMP Workshops.

\section{REFERENCES}

Aksnes, D.L., J.K. Egge, R. Rosland and B.R. Heimdal. - 1994. Representation of Emiliania huxleyi in phytoplankton simulation models-a first approach. Sarsia, 79: 291-301.

Barber, R.T. - 1992. Introduction to the WEC88 Cruise: an investigation into why the equator is not greener. J. Geophys. Res., 97: 609-610.

Barber, R.T., and F.P. Chavez. - 1991. Regulations of primary productivity rate in the equatorial Pacific. Limnol. Oceanogr., 36: 1803-1815.

Boyd, P.W. et al. -2000 A mesoscale phytoplankton bloom in the polar Southern Ocean stimulated by iron fertilization Nature, 407: 695-702

Broecker W.S. and T-H. Peng. - 1982. Tracers in the Sea, Eldigio Press, New York.

Brzezinski, M.A. - 1985. The Si:C:N ratio of marine diatoms. Interspecific variability and the effect of some environmental variables. J. Phycol., 21: 347-357.

Carr, M-E., N.S. Oakey, B. Jones and M.R. Lewis. - 1992. Hydrographic patterns and vertical mixing in the equatorial Pacific along $150^{\circ} \mathrm{W}$. J. Geophys. Res., 97: 611-626.

Chai, F., S.T. Lindley and RT. Barber. - 1996. Origin and maintenance of a high $\mathrm{NO}_{3}$ condition in the equatorial Pacific. Deep Sea Res. II, 43: 1031-1064.

Chai, F.R.C. Dugdale, T-H Peng, F.P. Wilkerson, and R.T. Barber. - (In press). One dimensional ecosystem model of the equatorial Pacific upwelling system, Part I: Model development and silicon and nitrogen cycle. Deep-Sea Res. II

Charles, D.C., P.N. Froelich, M.A. Zibello, R.A. Mortlock and J.J. Morley. - 1991. Biogenic opal in Southern Ocean sediments over the last 450,000 years: implications for surface water chemistry and circulation. Paleoceanography, 6: 697-728.

Chavez, F.P., K.R. Buck, S.K. Service, J. Newton, and R.T. Barber. - 1996. Phytoplankton variability in the central and eastern tropical Pacific. Deep-Sea Res. II, 43, 835-870

Coale, K.H. et al. - 1996. A massive phytoplankton bloom induced by an ecosystem-scale iron fertilization experiment in the equatorial Pacific Ocean. Nature, 838: 495-501.

Cullen, J.J., M.R. Lewis, C.O. Davis and R.T. Barber. - 1992. Pho- tosynthetic characteristics and estimated growth rates indicate grazing is the proximate control of primary production in the equatorial Pacific. J. Geophys. Res., 97: 639-654.

Davis, C.O., N.F. Breitner and P.J. Harrison. - 1978. Continuous culture of marine diatoms under $\mathrm{Si}$ limitation, 3. A model of Silimited diatom growth. Limnol. Oceanogr., 23: 41-52.

Droop, M.R. - 1974. The nutrient status of algal cells in continuous culture. J. Mar. biol. Ass.. U.K., 54: 825-855.

Dugdale, R.C. - 1967. Nutrient limitation in the sea: Dynamics, identification, and significance. Limnol. Oceanogr., 12: 685695.

Dugdale, R.C. - 1976. Modelling. In: E.D. Goldberg and J.H. Steele (eds.), The Sea, Ideas and Observations on Progress in the Study of the Seas, pp. 789-806. John Wiley, N.Y. Vol 6:.

Dugdale, R.C., R.T. Barber, F. Chai, T.H. Peng and F.P. Wilkerson. - (In press a). One dimensional ecosystem model of the equatorial Pacific upwelling system, Part II: Sensitivity analysis and comparison with JGOFS EqPac data. Deep-Sea Res. II.

Dugdale, R.C. and F.P. Wilkerson. - 1991. Low specific nitrate uptake rate: a common feature of high-nutrient, low-chlorophyll marine ecosystems. Limnol. Oceanogr., 36: 1678-1689.

Dugdale, R.C. and J.J. Goering. - 1967. Uptake of new and regenerated forms of nitrogen in primary productivity. Limnol. Oceanogr., 12: 196-207.

Dugdale, R.C. and F.P. Wilkerson. - 1992. Nutrient limitation of new production. In: P.G. Falkowski and A.D. Woodhead (eds.), Primary Productivity and Biogeochemical Cycles in the Sea, pp. 107-122. Plenum Press, New York.

Dugdale, R.C. and F.P. Wilkerson. - 1998. Silicate regulation of new production in the equatorial Pacific upwelling, Nature, 391: 270-273.

Dugdale, R. C., F.P. Wilkerson, R.T. Barber and F.P. Chavez. 1992. Estimating new production in the equatorial Pacific Ocean at $150^{\circ} \mathrm{W}$. J Geophys. Res., 97: 681-686.

Dugdale, R.C., F.P. Wilkerson and H.J. Minas. - 1995. The role of a silicate pump in driving new production. Deep-Sea Res., 42: 697-719.

Dugdale, R.C., A.G. Wischmeyer, F.P. Wilkerson, R.T. Barber, F. Chai, M. Jiang and T-H. Peng. - (In press b). Meridional asymmetry of source nutrients to the equatorial upwelling ecosystem: potential impact on ocean-atmosphere $\mathrm{CO}_{2}$ flux. Deep-Sea Res. II.

Dunne, J.P., J.W. Murray, A.K. Aufdenkampe, S. Blain and M. Rodier. - 1999. Silicon-nitrogen coupling in the equatorial Pacific upwelling zone, Global Biogeochem. Cycles, 13(3): 715-726.

Egge, J.K. and D.L. Aksnes. - 1992. Silicate as a regulating nutrient in phytoplankton competition. Mar. Ecol. Prog. Ser., 83: 281-289.

Eppley, R.W. and B.J. Peterson. - 1979. Particulate organic matter flux and planktonic new production in the deep ocean. Nature, 282: $677-680$

Fine, R.A., R. Lukas, F.M. Bingham, M.J. Warner and R.H. Gammon. - 1994. The western equatorial Pacific: a water mass crossroads. J. Geophys. Res., 99: 25063-25080.

Flynn, K.J. and V. Martin-Jezequel. - 2000. Modelling Si-N-limited growth of diatoms. J. Plankton. Res., 22: 447-472.

Franck, V.M., M.A. Brzezinski, K.H. Coale and D.M. Nelson. 2000. Iron and silicic acid availability regulate $\mathrm{Si}$ uptake in the Pacific sector of the Southern Ocean. Deep-Sea Res. II, 47: 3315-3338.

Frost, B.W. and N.C. Franzen. - 1992. Grazing and iron limitation in the phytoplankton stock and nutrient concentration: a chemostat analogue of the Pacific equatorial upwelling zone. Mar. Ecol. Prog. Ser., 83: 291-303.

Goldman, J.C. 1988. Spatial and temporal discontinuities of biological processes in pelagic surface waters. In: B.J. Rothschild (ed.), Towards theory on biological-physical interactions in the world ocean, pp.273-296. Kluwer.

Harrison, K. - 2000. Role of increased marine silica input on paleopCO 2 levels. Paleoceanography, 15: 292-298.

Ku, T.L., S. Luo, M. Kusakabe and J.K.B. Bishop. $-1995 .{ }^{228}$ Raderived nutrient budgets in the upper equatorial Pacific and the role of "new" silicate in limiting productivity. Deep-Sea Res. II, 42: 479-497.

Landry, M.R., R.T. Barber, R.R. Bidigare, F. Chai, K.H. Coale, H.G. Dam, M.R. Lewis, S.T. Lindley, J.J. McCarthy, M.R. Roman, D.K. Stoecker, P.G. Verity and J.R. White. - 1997. 
Iron and grazing constraints on primary production in the central equatorial Pacific: An EqPac synthesis. Limnol. Oceanogr., 42: 405-418.

Levitus, S., J.L. Reid, M.E. Conkright and R. Najjar. - 1993. Distribution of nitrate, phosphate and silicate in the world oceans. Progr. Oceanogr., 31: 245-273.

Leynaert, A., P. Treguer, C. Lancelot and M. Rodier. - 2001. Silicon limitation of biogenic silica production in the Equatorial Pacific. Deep-Sea Res. I, 48: 639-660.

Lukas, R., E. Firing, P. Hacker, P.L. Richardson, C.A. Collins, R.A. Fine and R. Gammon. - 1991. Observations of the Mindanao Current during the western equatorial Pacific Ocean circulation study. J. Geophys. Res., 96: 7089-7104.

Lyle, M., D.W. Murray, B.P. Finney, J. Dymond, J.M. Robbins and K. Brooksforce. - 1988. The record of Late Pleistocene biogenic sedimentation in the eastern Tropical Pacific Ocean. Paleoceanography, 3: 39-59.

Martin, J.H. and IronEx team - 1994. Testing the iron hypothesis in ecosystems of the equatorial Pacific Ocean. Nature, 371: 123-129.

McCarthy, J.J., C. Garside, J.L. Nevins and R.T. Barber. - 1996. New production along $140^{\circ} \mathrm{W}$ in the equatorial Pacific during and following the 1992 El Niño event, Deep-Sea Res. II, 43: 1065-1093.

Michaels, A.F. and M.W. Silver. - 1988. Primary production, sinking fluxes and the microbial food web. Deep-Sea Res., 35: 473490.

Milliman, J.D., K.L. Farnsworth and C.S. Albertin. - 1999. Flux and fate of fluvial sediments leaving large islands in the East Indies. J. Sea Res., 41: 97-107.

Minas, H.J., M. Minas and T.T. Packard. - 1986. Productivity in upwelling areas deduced from hydrographic and chemical fields. Limnol. Oceanogr., 31: 1182-1206.

Mortlock, R.M., C.D. Charles, P.N. Froelich, M. Zibello, J. Saltzman, L.D. Burkle and J.D. Hays. - 1991. Evidence for lower productivity in the Antarctic Ocean during the last glaciation. Nature, 351: 220-223.

Murray, J.W., E. Johnson and C. Garside. - 1995. A U.S. JGOFS process study in the equatorial Pacific (EqPac): introduction. Deep Sea Res. II, 42: 275-293
Nelson, D.M. and M.A. Brzezinski. - 1990. Kinetics of silicic acid uptake by natural diatom assemblages in two Gulf Stream warm-core rings. Mar. Ecol. Prog. Ser., 62: 283-292.

Nelson, D.M. and P. Treguer. - 1992. Role of silicon as a limiting nutrient to Antarctic diatoms: evidence from kinetic studies in the Ross Sea ice-edge zone. Mar. Ecol. Prog. Ser., 80: 255-264.

Nelson, D.M., et al. - (in press). A seasonal progression of Si limitation in the Pacific sector of the Southern Ocean. Deep Sea Res. II.

Peña, M.A., M.R. Lewis and W.G. Harrison. - 1990. Primary productivity and size structure of phytoplankton biomass on a transect of the equator at $135^{\circ} \mathrm{W}$ in the Pacific Ocean. Deep-Sea Res., 37: 295-315.

Philander, S.G. - 1990. El Niño, La Niña and the Southern Oscillation, Academic Press Inc, New York.

Pondaven, P., O. Ragueneau, P. Treguer, A. Hauvespre, L. Dezlieau and J.L. Reyss. - 2000. Resolving the "opal paradox" in the Southern Ocean. Nature, 405: 168-172

Ragueneau, O., P. Treguer, A. Leynaert, R.F. Anderson, M.A. Brzezinski, D.J. DeMaster, R.C. Dugdale, J. Dymond, F.G. Fischer, R. Francois, C. Heinze, E. Maier-Reimer, V. Martin-Jezequel, D.M. Nelson and B. Queguiner. - 2000. A review of the Si cycle in the modern ocean: recent progress and missing gaps in the application of biogenic opal as a paleoproductivity proxy. Global and Planetary Change, 26: 317-365.

Sigman, D.M. and E.A. Boyle. - 2000. Glacial/interglacial variations in atmospheric carbon dioxide. Nature, 407: 859-869.

Smetacek, V. - 1999. Diatoms and the ocean carbon cycle, Protist, 150: $25-32$

Toggweiler, J.R. and S. Carson. - 1995. What are upwelling ecosystems contributing to the ocean's carbon and nutrient budgets? In: C.P. Summerhayes, K.-C. Emeis, M.V. Angel, R.L. Smith and B. Zeitschel (eds.), Upwelling in the Ocean, Modern processes and ancient records, pp. 337-361. Wiley and Sons.

Tsuchiya, M. - 1991. Flow path of the Antarctic Intermediate Water in the western equatorial South Pacific Ocean. Deep Sea Res., 38: $273-279$

Walsh, J.J. - 1976. Herbivory as a factor in patterns of nutrient utilization in the sea. Limnol. Oceanogr., 21: 1-13. 